\title{
Fishing Tourism can Support Fisher's Livelihood and Fish Conservation in Nepal: A Value Chain Analysis
}

Dr. Tek Bahadur Gurung and Amar Thing

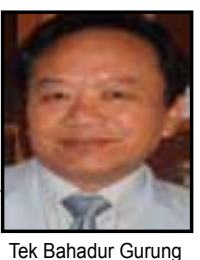

Abstract: Fishing tourism of recreational fisheries is a multibillion dollar outdoor activity. The fishing tourism in Nepal is yet to be systematized. Focusing on this need, the present paper attempts to pioneer how recreational fisheries in Nepal could be useful having commendable world renounced fish resources, luring pristine and suitable scenic landscapes for promoting fishing tourism. It is argued that fishing tourism should be systematically regularized and practised in close collaboration with traditional ethnic fisher communities. Considering the potentiality, we elucidate the result of value chain analysis, arguing that promotion and streamlining of fishing tourism along with the traditional fishers could generate immense livelihood opportunities for resilience along with fish conservation. The value chain analysis showed that livelihood of fishers communities are likely to be enhanced by involving in fishing based tourism support services with fewer fishing activities, which in turn could be supportive to fish conservation. The present modality of promoting and systematizing fishing tourism might have implication to address the issues of poverty alleviation and resilience to fish conservation in many developing countries having similar socio-economic and agroecological setups in Nepal.

Keywords: Recreational fishing tourism, poverty, conservation, value chain, Nepal

\section{Introduction}

Nepal is the "Himalayan Shangri-La" having 1 abundant intrinsic water tributaries flowing down from world renowned pristine highest mountains of the world contributing into three major river systems endowed with 229 fish species and traditional fishing communities within a span of 800 $\mathrm{km}$ from east to west of the country. These features suggest that Nepal could be one of the world's ideal inland fishing destinations. Fishing tourism has been well recognized as contributors to local, national and regional economies throughout the world (April et al. 2011; Cordell et al. 1999). The fishing tourism has been a part of international and global concern (Cowx et al. 2010; Travis et al. 2014). The tourism industry accounted for $8 \%$ of the world's gross domestic product and about $9 \%$ of the world's employment (Goeldner et al. 2000). In general, primary objective of fishing tourism might be towards sport and leisure; but secondarily the purpose could mean for consumption (FAO, 1997; Pitcher and Hollingworth, 2002; EIFAC, 2008; Arlinghaus and Cooke, 2008) and conservation etc.

The value chain of fishing tourism covers a wide and multiple activities including transportation using planes, buses, boats for participation in fishing activities, visiting river beach and national parks etc. The value chain also extends to use of accommodations such as hotel, lodge, camps etc, opportunities to sell food and beverages and groceries etc., clothing and equipment for fishing wear, souvenirs, fishing tackle, bait, rod-line, camping essentials, outfits, out boat engines, house boats, tourist information centers, internet services, travel guide book, advertising, maps, musical, cultural, historical, geographical information, brochures etc (Goeldner et al. 2000).

Sowman (2006) mentioned fishers involved in subsistence fishing are poor. Fishers often living nearby rivers, tributaries, lakes and wetlands for easy access to aquatic food mainly capture fish, crabs, snails, and collect water chest nut and other vegetation mostly free of cost to meet basic needs, but not for leisure. The dependency on aquatic food is mostly due to scarcity of agricultural land, particularly in the Himalayan regions.

Inland native fishers often possess limited knowledge on their role on fish resource conservation (Gurung 2003; Granek et al. 2008). This might be one of the reasons that fish biodiversity has declined, fishers getting poorer and conflict between fishers and conservationist widening. It can be argued that the conflict between fishers and National Park in Nepal (Jana 2007) might be due to inadequate analytical synthesis between conservationists and fishers. Therefore, the role and responsibilities of traditional fishers should also be analyzed for effective planning (Travis et al. 2014; WB 2010). Recent studies have shown that aboriginal fishing communities have suffered a great deal of deprivation due to conceptual changes of nature conservation such as in Chitwan National Parks in Nepal (Bhattarai et al. 2002; Jana, 2007; Paudel et al. 2007). The studies concluded that the government policies indeed are the main encroachers to ethnic rights of common, especially those dependent on traditional practices of their fishing activities (Bhattarai et al. 2002).

Fish angling as major activities of the recreational fisheries is enjoyable time pass outdoor life, having potentialities to be a powerful economic engine for society (Ditton et al. 2002; Bauer). However, the sector is merely known due to poor understanding, lack of accessible information, initiatives to promote fishing tourism economic dimensions and importance (Douglas et al. 2011) in Nepal. In such circumstances, it is anticipated that promoting fishing tourism involving traditional deprived fishers into the value chain might share benefit for livelihood and resilience in conservation. Thus, the present paper elucidates a value chain analysis, showing how participatory approach of recreational fisheries development could provide employment opportunities to traditional fishers and support fish conservation. 


\section{Model Overview for Value Chain Analysis}

The present work was carried out, using the tools of value chain analysis (Riley 2012; Porter 1998), extensive literature search, and interactions with fishing tour experts, entrepreneurs, fishers and anglers. Since one of the motives of the fishing tourism is to reduce pressure and increase awareness of illegal fishing by involving fisher communities in the value chain. Thus, the program should be implemented cautiously in close collaboration with fishers and other beneficiaries. In this model, majority of the fishers would have new responsibilities and opportunities to deal with. Past experiences suggest that participatory approach with fishers were successful (Gurung 2003; Gurung et al. 2005), however, securing their roles would be important in newly created value chain options. In line with these, several studies demonstrated that fishers might offer unique potential of enhancing fish conservation (Granek et al. 2008; Bate 2001), because of theirs inherent interest in the conservation and management of the fisheries resources (Arlinghaus 2006; Arlinghaus et al. 2002). Allowing fishers to participate in developing regulations, within the bounds set by available stock information from biologists could lead to increased management success (Sullivan 2003; Travis et al. 2014).

Our model incorporated the key interactions between anglers, fish stocks, response of fishers and tourism entrepreneurs (Figure. 1). The model was structured keeping in view that there would be business opportunities if local coordination among tour operators and fishers could be managed.

Fishing tour could be organized in close collaboration and cooperation between tour operators and local fishers. The fishing tourism would also involve occasional shopping, eating, boating excursion and other recreational activities. The fishing tourism might involve fishers as guides, transporters and merchants of local agriculture and livestock fish products (Figure. 2). It has been stipulated that involvement of traditional fishers in different jobs and income opportunities such as in transportation and service sector created by fishing tourism would divert majority from fishing to other income activities.

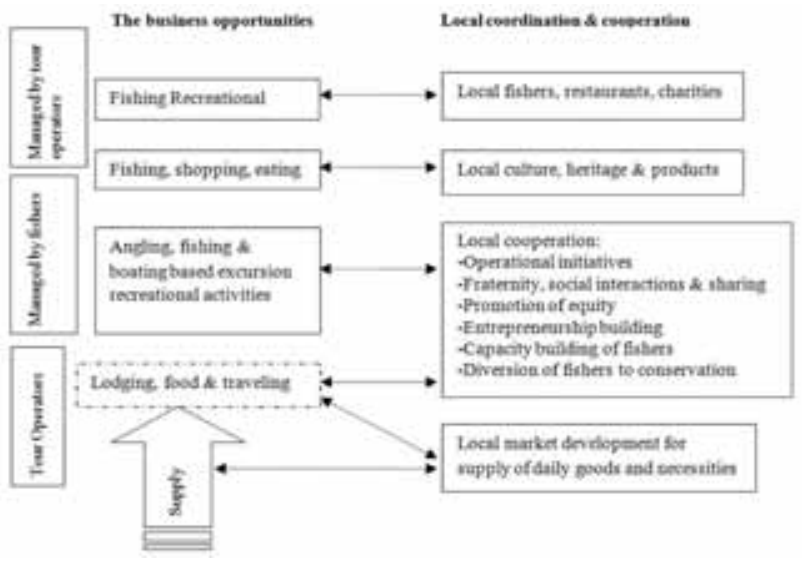

Figure 1: Fishing tourism linkage into the local economy for livelihood support to fishers fish poor fisfishers fishers

\section{Results and Discussion}

The result showed that an ample job and income opportunities could emerge in the fishing tourism for poor fishers and other stakeholders already existing in the business (Figure. 1). Local coordination and cooperation among stakeholders might create jobs in food catering sector, transport, market opportunities of local products, handicrafts and arts as depicted in Figure. 1 and 2.
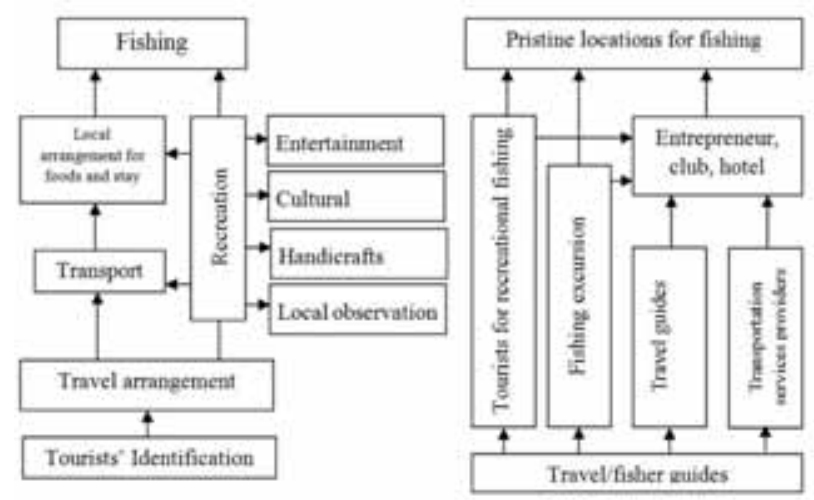

Figure 2: Value chain map of recreational fishing tourism

Since the fishing tourism value chain might create livelihood opportunity to fishers and it might be expected that many of traditional fishers would be involved in new job opportunities, meanwhile it is expected that the fishers' engagement in new activities would impact on low fishing which earlier experiencing high fishing pressure, one of the causative factors of fish biodiversity conservation issues (Figure. 3).
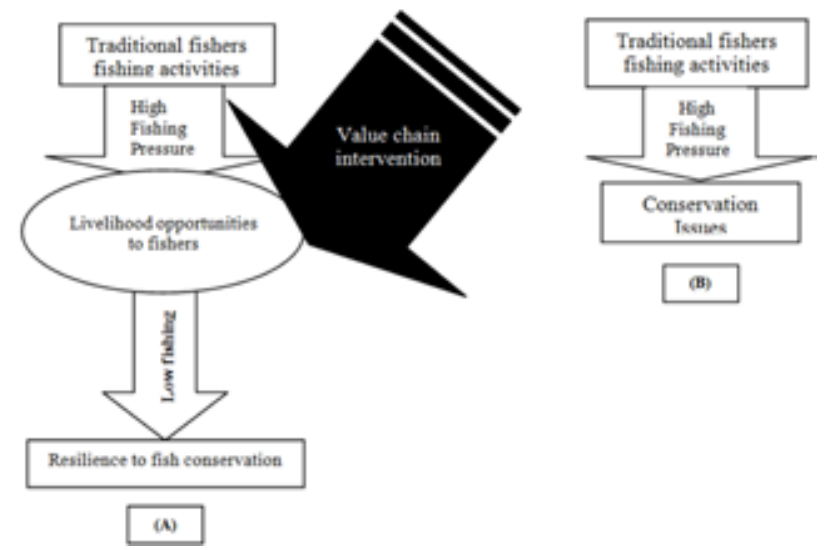

Figure 3: Fishing tourism intervation reduces fishing pressure to support fish conservation (aA) comparing to high pressure traditional system (B)

In many parts of the world, involvement of the poor in tourism has been successful in mainstreaming them for improved livelihood (Caroline et al. 2000; Ditton et al. 2002). However, efforts of involved fishers in fishing tourism aiming at livelihood enhancement and fish resource conservation together is a new approach, which in turn might resolve the conflicting relationship between fishers and national park administration.

The fundamental principle of fishing tourism is high effort and low catch contrasting to low effort with high catch of traditional fisheries (Pereira 
and Hansen, 2003). This approach could be highly relevant in Nepalese waters for fish conservation, which is supposed to have been overfished (IUCN 2004; Gurung 2011). Thus, fishing tourism can be highly relevant to conservation strategies in natural waters. It is known that fisheries attracting and drawing national and international visitors contribute healthily and substantially to economic empowerment (IFS 2007). Here, it is noted that basic principle of fishing tourism adopted in the model is better profitability and sustainability through mobilizing value chain associated with it. A detailed study of developing fishing destinations in Nepal is yet to be done.

\section{Strategic Plan of Action for Active Participation of Value Chain Actors}

For participatory approach of fishing tourism by involving poor and deprived fishers, business model approach of 'Push and Pull" theory would be useful (Fritsch and Rusakova 2011; Maki 2010) to assure involvement of fishers in associated value chains. This would be important in Nepalese socio-economic or likewise context. It is essential to involve the fishing communities because largely the fishers are often landless having almost no agricultural land and livestock resources, entirely depending on fishing for livelihood with extremely poor social values and recognition. These groups have been largely ignored in government policies as there are only few supporting program to address poor fishers under food and nutritional security plan.

\section{Act, Law and Policy Exist for Mainstreaming Value Chain of Fishing Tourism}

Regulation of fishing by government agencies is common practice worldwide. Government of Nepal has also promulgated 'Aquatic Life Conservation Act, 1940. Despite that, the Act could not adequately address the fish biodiversity conservation (Gurung 2012). Much priority has been on regulation and management of terrestrial wildlife and as a result several national parks and protected areas have been declared in the country. This probably has caused a gap and conflict in between the park and communities subsisting on aquatic ecosystem for their livelihood.

Aquatic Life Conservation Act, 1940 has provisioned that government officials could authorize nearby water bodies for fishing activities. There are additional ordinance from the Ministry of Agricultural Development, which delineates size of fish and species in particular season to protect the fish species during the spawning season. Following the Act, 1940, Fisheries Research Station, Pokhara issues license since its establishment for angling, cast net fishing and use of gill net etc. National Parks are also known to be issuing the license for fishing. Other agencies issuing the license for fishing in Nepal are not known.

There exist amateur fishing clubs and associations in Nepal. Some aquaculture farmers also insisted to incorporate their fish farms as one of the spots as tourism based fisheries activities. These fishing clubs and farms are known to organize fishing activities in private owned farms and potential sites, such as Arun Valley Rivers in the east and Lake Phewa, Begnas etc in Pokhara. The clubs, associations and farms might need to be streamlined to initialize recreational tourism based fisheries for better benefits.

\section{Is Nepal an Ideal Destination for Fishing Tourism?}

Promotion of recreational fishing tourism is likely to be a success, similar to other sectors of tourism in Nepal. For successful fishing tourism enterprise, abundant piscivore species are considered ideal for angling which can be captured using bait. Pristinely pleasing and secured surroundings close to the fishing location are preferred as an ideal location. Such fishing location should be close to the roads for easy access facilities. The tourism service facilities for outfits, guides, fishing equipment and lures should also be available nearby. Money exchange and overnight staying facilities for several weeks stay, other leisure and recreation besides fishing and angling would also be desirable.

Nepal is endowed with about 6000 rivers and tributaries feeding three main river systems in Nepal. These rivers, tributaries and other forms of inland waters are known to harbor about 229 fish species in Nepal (Wagle and Pradhan, 2012). Out of these, some are globally known to be magnificent for sport fish of the world, such as Tor putitora, Acrossocheilus hexagonolepis, Shizothaorax spp, Oncorhynchus mykiss and several others including carp used for cultivation purpose (MacDonald 1948; Gurung and Baidya, 2011). These fishes having global reputation for game and recreation for their sporting, tackling and fighting capabilities are available in Nepalese mid hills and inner terai waters from east to west.

The natural landscape of Nepal is world renowned for its world's tallest peaks, scenic beauty and diversity. Similarly, fish composition in Nepal is almost similar to the rest of the world dominated by cypriniformes (Mayden et al. 2008). Moreover, geographical, ethnic and cultural diversity of the country are additional attractions for travelers in the country. Accumulatively, the resources and geographical setting of Nepal is expected to be highly suitable for developing fishing tourism.

Nepal also has rich traditions and culture. Several of ethnic communities have been depicted to be water and fishing dependent either in mountains or flat areas from east to west since time immortal. Such ethnic communities inhabiting mostly close to water bodies with great skill of traditional fishing outfit use, however, modern fishing tools might be a puzzle, but soon can be the master of the game, if acquainted for short exposure.

\section{Resolving Conflict between National Parks Policies and Fishers}

Some of the national parks in Nepal have included several villages and other forms of human settlement inside. This kind of inter dependency often invites conflicts in between the park administration and local communities (Bhattarai et al. 2002; Jana 2007). Human settlement inside the park could be beneficial if some model of win-win interaction in between the park and people could be drawn. Recently, interesting 
works on conflict between fishing communities living along the bank of Narayani River in south central Nepal within Royal Chitawan National Park has been highlighted (Dahal and Chapagai 2008; Jana 2007; Paudel et al. 2007). The poor fisher communities have raised several issues to be resolved on their traditional rights of fishing in the river through campaigns (Higginbottom 2003; Hofer 2002; Jana 2007). It is learnt that the park administration harasses the fishers (Bhattarai et al. 2002). Different political parties showed their sympathy towards their cause but they did very little in changing the situation. Such a conflict has been reported from Chitawan, Nawalparasi and Saptari districts. It is also known that park authorities allowed fishers to fish in the river for six months. Park administration collects revenue from tourist entry fee as well as permitting the fishing through licensing. To reduce the conflict in between park administration and local fishers, the approach of value chain recreational fishing tourism could be one where the local fishers could be deviated from 'high' fishing pressure to other service oriented jobs for their livelihood. The park further might open new venues and opportunities, using the tourism value chain.

\section{Possible Impacts of Recreational Fishing Tourism on Fishers and Fish Conservation}

Several studies have been carried out on the impact of tourism based recreational fisheries worldwide (Coleman et al. 2004; Steven and Cowx 2006; Cowx et al. 2010) suggesting that tourism fishing is detrimental for fish conservation approaches (Regier et al.,1999; Westera et al. 2003). This fact, in general, has been acceptable. However, in prevailing socio economic context, where unconventional fishing deteriorates fish biodiversity (Gurung 2003, 2012), promoting tourism based recreational fisheries could be one of the safeguarding approaches for fish conservation by providing other livelihood options to traditional fishers through fishing tourism (Figure. 2, 3). It is expected that involving the poorest of the poor fishers into the tourism might rescue the fishes from being over-fished and the fishers from drudgery.

It is expected that fishing tourism can generate local cash income from formal employment, earnings from selling goods, services, or casual labour (e.g. food, crafts, building materials, and guide services), profits from locally-owned enterprises, profits from a community-run enterprise etc. Since the fishers would also be the partners in recreational fisheries, it is expected that the enterprise would create job opportunities to fishers in different aspects of value chain.

\section{Conclusion}

A general consensus on importance and positive attributes of fishers on conservation of fish is building up slowly worldwide, except little opinion that fishing tourism might be destructive. However, to reduce the fishing pressure which might directly impact on fish biodiversity, involvement of fishers in the value chain of fishing tourism must have positive attributes. Due to high effort and low catch, fundamental principles of fishing tourism could be one of the options of fish conservation together with livelihood enhancement for marginalized fishers in present socio-economic context. The value chain of fishing tourism includes transportation; and lodging in hotels and outdoor villages; participation in fishing, cultural, festivals excursions, purchasing, hiring of fishing rod, line, tent, clothing, boat, out-boat engines etc. The fishing tourism is highly potential but inadequate access to suitable location is hindering the promotional activities. Since the traditional fishers are world's 'poorest of the poor', the inclusion of such community in fishing tourism not only support their livelihood but also conserve fish diversity in a new approach.

\section{Acknowledgement}

We are thankful to the staff of Nepal Agricultural Research Council for their cooperation during the preparation of the manuscript. The participants of Society of Agricultural Scientists, Aquaculture Group are gratefully acknowledged for their comments and suggestions on the initial draft of this paper.

Tek Bahadur Gurung, $P h D$, is Principal Scientist (Fisheries) and Director of Livestock. Dr. Gurung graduated from Gorakhpur University, India and Kyoto University, Japan and pursued post doctorate studies as Fulbright Scholar at the University of Missori/Columbia, USA. He has devoted his career to fisheries and aquaculture research, especially on developing cold and aquaculture technologies and crap fish breeding in inner Himalayan foothills. Dr. Gurung has published over 50 papers in national and international peer reviewed scientific journals.

Corresponding E-Mail: tek_fisheries@hotmail.com

Amar Thing, Enterprise Development Expert, Nepal,

E-mail: thingamar@gmail.com

\section{References}

April J, Mayden R L, Hanner R. H., and Bernatchez L (2011) Genetic calibration of species diversity among North America's freshwater fishes, PNAS, 108, 26: 10602-10607.

Arlinghaus R. 2006. Overcoming human obstacles to conservation of recreational fishery resources, with emphasis on Europe. Environmental Conservation 33:46-59.

Arlinghaus R and S J Cooke. 2008. Recreational fisheries: socioeconomic importance, conservation issues and management challenges. In: B. Adams, (ed) Recreational hunting, conservation and rural livelihoods: science and practice. Blackwell Science, Oxford, United Kingdom.

Arlinghaus R, Mehner T, and I G Cowx. 2002. Reconciling traditional inland fisheries management and sustainability in industrialized countries, with emphasis on Europe. Fish and Fisheries 3:261- 316. 
Bauer J and A Herr. 2004. Hunting and fishing tourism. In: Wildlife Tourism: Impacts, Management and Planning, (ed) K. Higginbottom, (Altona, Australia: Common Ground Publishing), pp. 57-78.

Bate R. 2001. Saving our streams: the role of the Anglers' conservation association in protecting English and Welsh Rivers. The Institute of Economic Affairs and Profile Books, London.

Bhattarai A, A Thapalia, M Thapa and S Ghimire. 2002. Civil Society in Nepal: Some Self-Reflections (A research report prepared as a part of a research project carried out in

collaboration with Institute of Development Studies, University of Helsinki, Finland)

Nepal South Asia Centre (NESAC) Baluwatar, Kathmandu, http://nesac.org.np/main/pdf/ research_3_No_report.pdf

Caroline A, C Boyd, H Goodwin. 200o. Pro-poor tourism: putting poverty at the heart of the tourism agenda, Natural Resource perspectives Number 51. The Overseas Development Institute, Portland House, Stag Place, London SW1E 5DP, UK, ISSN: 13569228 (C) Overseas Development Institute 2000, www. oneworld.org/odi/nrp/

Coleman F C, W F Figueira, J S, Ueland, L B Crowder. 2004. The Impact of United States recreational fisheries on marine fish populations. Science 305, 1958-1960.

Cordell H K, B L McDonald, R J Teasley. 1999. Outdoor recreation participation trends. In: Cordell HK, editor. Outdoor recreation in American life: a national assessment of demand and supply trends. Champaign IL: Sagamore Publishing; p. 219-322.

Cowx I G, R Arlinghaus and S J Cooke. 2010. Harmonizing recreational fisheries and conservation objectives for aquatic biodiversity in inland waters. J. Fish Biol. 76, 2194-2215. (doi:10.1111/j.1095-8649.2010.02686.x)

Dahal G R and A Chapagai (2008) Community Forestry in Nepal: Decentralized Forest Governance Lessons from Forest Decentralization, pp 66-79

Ditton R B, M H Stephen and K A David. 2002. Recreational Fishing as Tourism, American Fisheries Society Symposium 30, Bethesda, Maryland. Ditton. Recreational fishing as tourism.

Douglas T. B Jr, Robert A., Cooke S J., Peter B. M, S De Silva, D Bartle and I G Cowx. 2011. Ecosystem approach to inland fisheries: research needs and implementation strategies, Biol. Lett. 7, 481-483.

Ditton R B, S M Holland and D K Anderson. 2002. Recreational Fishing as Tourism, Fisheries, 27:3, 1724.

EIFAC. 2008. EIFAC Code of Practice for Recreational Fisheries. EIFAC Occasional Paper. No. 42. Rome, FAO. 2008. www.fao.org/docrep/o12/io363e/ io363eoo.htm FAO European Inland Fisheries Advisory Commission

FAO. 1997. Inland fisheries, FAO Fisheries Department
Technical Guidelines for Responsible Fisheries No 6 (Technical guidelines for the sustainable management of inland fisheries).

Fritsch M, and A Rusakova. 2011. Entrepreneurial Choice across occupations: an empirical investigation of occupation-specific 'push'- and 'pull' factors. Friedrich Schiller University Jena, School of Economics and Business Administration., Chair of Business Dynamics, Innovation, and Economic Change Carl-Zeiss-Str. 3 D-o7743 Jena, Germany

Goeldner C R, Ritchie J R B and R W MacIntosh (2000). Tourism: Principles, Practices,

Philosophies, 8th ed. John Wiley \& Sons, Inc.: New York. Granek E F, E M P Madin, M A Brown, W Figuerra, D S Cameron, Z Hogan, G Kristianson, P E Villiers, J E Williams, J Post, S Zahn, ANDR Arlinghaus. 2008. Engaging Recreational Fishers in Management and Conservation: Global Case Studies, Conservation Biology, Volume 22, No.5, 1125-1134

Gurung T B, 2012. Native fish conservation in Nepal: Challenges and opportunities, Nepalese Journal of Biosciences 2: 71-79

Gurung T B. 2003. Traditional Fishers Work to Save Fish Species in Nepal's Lakes Russell E Train, Education for Nature Program, Education for nature Program, World Wildlife Fund, 1250, 24th Street,NW Washington DC 20037-1132, USA, p 1 and 5.

Gurung T B, Wagle S K, Bista J D, Dhakal R P, Joshi P L, Batajoo R, Adhikari P and Rai A K. 2005. Participatory fisheries management for livelihood improvement of fishers in Phewa Lake, Pokhara, Nepal, Himalayan Journal of Sciences 3(5): 47-52.

Gurung T B. 2011. Prospects of cold water fisheries in high altitude wetlands, Proceedings of the 8th National Workshop on Livestock and Fisheries Research, Nepal Agricultural Research Council, pp 1-9.

Gurung T B and A Baidya. 2012. Ex-situ Breeding Performance Using Pond- Reared Broods of Endangered Himalayan Golden Mahseer (Tor putitora) in Nepal. In: Chettri, N; Sherchan, U; Chaudhary, S; Shakya, B (eds) Mountain biodiversity conservation and management: Selected examples of good practices and lessons learned from the Hindu Kush Himalayan region. ICIMOD Working Paper 2/2012. Kathmandu: ICIMOD, p 70.

Higginbottom. 2004. Wildlife tourism : impacts, management and planning published by Common Ground Publishing Pty Ltd PO Box 463, Altona Vic 3018, ABN 66074822629 in association with Cooperative Research Centre for Sustainable Tourism http://www.crctourism.com.au, pp 297.

Hofer D. 2002. The Lion's share of the hunt. Trophy hunting and conservation, a review of the legal Eurasian tourist hunting market and trophy trade under CITES. TRAFFIC Europe.

IFS 2007 Inland Fisheries Service, Tasmania Annual Report (2007).

IUCN. 2004. A Review of the Status and Threats to 
Wetland in Nepal (eds S. Karki \& S. Thomas). Jagdamba Press, Hattiban, Lalitpur, India. $78+v$ pp.

Jana S. 2007. Working Towards Environmental Justice: An Indigenous Fishing Minority's Movement in Chitwan National Park, Nepal, International Centre for Integrated Mountain Development (ICIMOD), Kathmandu, Nepal, p 55.

Macdonald, A. St. J. 1948. Circumventing the mahseer and other sporting fish in India and Burma. Published by Bombay Natural History Society in Bombay . 306 $\mathrm{p}$

Maki. 2010. Push marketing versus pull marketing. Retrieved May 25, 2010 at http://www.doshdosh. com/push-marketing-vs-pull-marketing/ Written by: Ashley McDonough, AMAC Solutions

Mayden R. L., Tang L., Wood R M., Chen W-J, Agnew M K., Conway K W., Yang L, Simons A M., Bart H L. Harris P M., Junbing L, Wang X, Saitoh K, Shunping HE, Huanzhang L, Chen Y, Nishida M, Miya M (2008) Inferring the Tree of Life of the order Cypriniformes, the earth's most diverse clade of freshwater fishes: Implications of varied taxon and character sampling, Journal of Systematics and Evolution 46 (3): 424438.

Paudel K, Adhikari D, Paudel S. 2007. Reframing Livelihoods Strategies: Musahar/Bote's Ch a ng ing Livelihoods Contexts and their Responses to Diverse Development Interventions, A Study Report, Environmental Resource Institute, P.O. Box No. 12207 Kathmandu, Nepal. http://www.forestaction. org/

Pereira D L, M J Hansen. 2003. A perspective on challenges to recreational fisheries management: summary of the symposium on active management to recreational fisheries. North American Journal of Fisheries Management23, 1276-1282.

Pitcher T J, Hollingworth C E (2002) Fishing for fun: where's the catch? In: Pitcher T J Hollingworth C E (Eds.), Recreational Fisheries: Ecological, Economic and Social Evaluation. Blackwell Science, Oxford, pp. $1-16$.

Porter M E. 1998. Competitive Advantage - Creating and Sustaining Superior Performance. New York: The Free Press.

Regier H A, Whillans T H, Christie W J and Bocking S A (1999) Over-fishing in the Great Lakes: the context and history of the controversy. Aquatic Ecosystem Health and Management 2: 239-248.

Riley, J. 2012. Value chain analysis, http://www.tutor2u. net/blog/index.php/site/author/11/

Sowman, M. 2006. Fisheries reform in South Africa 1994-2004. Marine Policy, 30(1): 60-73.

Steven J C, I G Cowx (2006) Contrasting recreational and commercial fishing: Searching for common issues to promote unified conservation of fisheries resources and aquatic environments Biological Conservation 128(2006) $93-108$

Sullivan, M. G. 2003. Active management of walleye fisheries in Alberta: dilemmas of managing recovering fisheries. North American Journal of Fisheries Management 23:1343-1358.

Travis J, F. C. Coleman, P. J. Auster, P. M. Cury, J. A. Estes, J. Orensanz, C. H. Peterson, M. E. Power, R. S. Steneck and J. T. Wootton (2014) Integrating the invisible fabric of nature into fisheries management, Proceedings of National Academy of Sciences, 111: 2: 581-584

Wagle S. K; N. Pradhan 2011 Proceedings of the consultative workshop on fish conservation in Nepal, (eds) Fisheries Research Division Godawari, Lalitpur, Nepal x+220 pp

Westera M, Lavery P and Hyndes G. 2003. Differences in recreationally targeted fishes between protected and fished areas of a coral reef marine park. Journal of Experimental Marine Biology and Ecology, 294: 145168.

World Bank (2010) The hidden harvests the global contribution of capture fisheries Agriculture and Rural Development Department Sustainable Development Network

Prepared by the World Bank, Food and Agriculture Organization, World Fish Center, Agriculture and Rural Development Department Sustainable Development Network 